\title{
Mixed Cell Adenoma
}

National Cancer Institute

\section{Source}

National Cancer Institute. Mixed Cell Adenoma. NCI Thesaurus. Code C4157.

An adenoma characterized by the presence of a mixed epithelial cell population. 